\section{Varmt og klokt om legegjerningen}

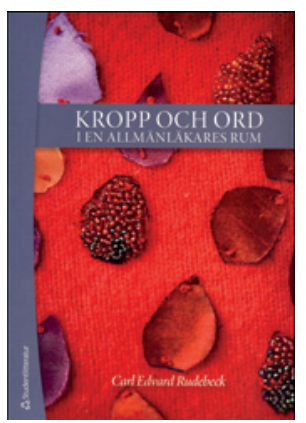

Carl Edvard Rudebeck Kropp och ord i en allmänläkares rum 205 s, ill. Lund: Studentlitteratur, 2012 Pris SEK 242

ISBN 978-91-44-07832-8

Omslaget er perlebroderier utført av forfatterens kone, som også står for illustrasjonene. Boken er i seg selv en perle som forbauser og fascinerer med gjennomtenkte erfaringer og refleksjoner over legegjerningen. Det sentrale temaet er møtet mellom pasient og lege, illustrert i tallrike, korte, men poengterte og lett gjenkjennelige vignetter som ofte avslutter kapitlene. Men temaet er også livet selv, opplevd i kropp og tanker av så vel den enkelte pasient som av den erfarne allmennlegen - en lege som reflekterer både ut fra egen livserfaring og fra mangfoldige pasientmøter. Et gjennomgående «du» til leseren bidrar til at boken blir intim og utfordrer til refleksjoner. Det som i tillegg gir leseglede, er et vakkert, ofte poetisk språk med fyndige utsagn: «Ditt liv har satt sig i din kropp trots att du inte är gammal», «Du (...) märker at du inte kan gripe den skiva du siktat dig inn på. Handen är plötsligt intet annat än en oavslutad handling» og «Psykisk hälsa är et allvarets lättsinne; ett under lika stort som kroppsligt välbefinnande.»

Boken starter med en «läsanvisning», der forfatteren begrunner de gjennomgående vignettene med «Mötet» og «Existentiell anatomi» - kroppen som den oppleves. Forfatteren redegjør også for balansen mellom referert faglitteratur og klinisk erfaring. Utgangspunktet, å ha det bra, beskrives. Så starter første kapittel om ikke å ha det bra, med diskusjon av symptomet, og av de forandringene som ikke forsvinner. I del 2 om lege-pasient-møtet reflekterer han over beredskap, kompleksitet, makt, beslutninger og følelser. I del 3 er det en moderne og konstruktiv kritikk av pasientsentrerthet og av den biopsykososiale modellen for medisinsk forståelse, før korte kapitler om familie, kjønn, kultur, klasse og arbeid, og en kort epilog: «Respekten för dig är respekten för skillnaden (...) Det förnyande mötet er det naturliga. Det definierade är kraftödande försvar av det givna.»

Forfatteren er en erfaren svensk allmennlege som også er professor II ved Universitetet i Tromsø. Han har vært opponent for flere norske doktorander, og selv har jeg i studentundervisning ofte brukt tanker fra hans doktoravhandling som handler om hva klinisk kompetanse er (1). Ja, Carl Edvard er en venn, og det er en interessekonflikt jeg bør si fra om. Men min anmeldelse hadde ikke vært annerledes om forfatteren hadde vært ukjent. Det er en bok som har allmenn interesse for leger, og som fortjener å bli oversatt til flere språk. Men nordmenn bør unne seg å lese hans vakre svenske prosa. Målgruppen kan godt inkludere allmennheten, som vil kjenne seg igjen i mange av refleksjonene og i noen av sine egne møter med leger. Etter hvert en klassiker?

Knut Arne Holtedahl

Institutt for samfunnsmedisin

Universitetet i Tromsø

Litteratur

1. Rudebeck CE. General practice and the dialogue of clinical practice:

on symptoms, symptom presentations, and bodily empathy. Doktoravhandling.

Scand J Prim Health Care 1991: 10 (suppl 1).

Oppgitte interessekonflikter: Anmelderen er arbeidskollega og venn av forfatteren.

\section{Fra luftfart til effektivitetsfremmende ledelse i sykehus}

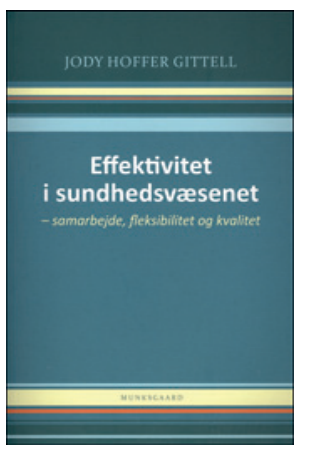

\section{Jody Hoffer Gittell \\ Effektivitet i sundhedsvæsenet}

Samarbejde, fleksibilitet og kvalitet. 313 s, tab, ill. København: Munksgaard Danmark, 2012.

Pris DKK 298

ISBN 978-87-628-1136-2

Luftfartsindustriens kvalitetsarbeid blir av mange ansett som en tilnærmet gullstandard for sikkerhetsarbeid, om enn ikke alltid samtidig en gullstandard for effektivitet.

Forfatteren, som er økonom og samfunnsviter, har sammenliknet prosesskvalitet i luftfartsindustrien og i helsetjenesten. Hennes hovedbudskap er knyttet til begrepet «relationell koordinering»å koordinere arbeid gjennom relasjoner bygd på felles mål, felles kunnskap og gjensidig respekt, og som et verktøy for å implementere relasjonell koordinering og å måle effektene av dette. Målgruppen er ledere som er opptatt av organisasjonsutvikling i store helsevirksomheter.

Hoffer Gittell fremhever at nødvendig logistikk for å oppnå regularitet i flytrafikkavvikling har mange fellestrekk med logistikk i sykehus, og hun peker på egne pasienterfaringer som en viktig aha-opplevelse for å se dette.

Hun sammenlikner samspillet mellom kabinpersonale, stuere, piloter, mekanikere og kundebehandlere på bakken med situasjonen $i$ helsevirksomheter. Det er behov for et tett samspill mellom forskjellige yrkesgrupper $\mathrm{i}$ et hierarkisk system hvor pilotene - og legene - er på toppen av pyramiden, og nettopp derfor må være særlig samspillkompetente.

Hennes problembeskrivelse av USAs helsevesen passer rimelig godt på det norske, med fragmenterte IKT-systemer, effekter og bivirkninger av innsatsstyrt finansiering, budsjettunderskudd og slitne fotfolk som opplever at relasjonen til pasientene ødelegges av trange rammer og høye effektivitetskrav.

Teksten er tematisk oppbygd med hovedkapitler om endring av helsevesenet og oppbygging og innføring av et samlet ledelsessystem. Forfatteren vektlegger at systematisk effektivitets- og kvalitetsarbeid og målinger er avgjørende, og at man ikke bør fremheve oppfølging av avvikshendelser med ledsagende «naming, blaming and shaming».

Er boken nyttig for ledere i norske sykehus? Svaret avhenger av perspektivet. Noen lærebok i sykehusledelse er den ikke, men den er velegnet til å gi påfyll og perspektiv for dem som har arbeidet med ledelses- og systemutfordringer over lengre tid. Den er lettlest og krydret med anonymiserte sitater fra helseledere med høy gjenkjennelsesfaktor - også for oss her på berget.

\section{Jan Emil Kristoffersen}

Akershus universitetssykehus 